\title{
EMOTIONAL LABOR, QUALITY OF WORK LIFE, AND LIFE SATISFACTION OF TOUR GUIDES: THE MEDIATING ROLE OF BURNOUT ${ }^{1}$
}

\author{
Derya Demirdelen Alrawadieh ${ }^{\mathrm{a},}$, Mithat Zeki Dincer ${ }^{\mathrm{b}}$ \\ a Department of Hotel, Restaurant and Catering Services, Istanbul Ayvansaray University, Istanbul, Turkey. \\ ORCID: 0000-0002-7554-2256 / e-mail:deryademirdelen@gmail.com \\ ${ }^{\mathrm{b}}$ Department of Economic Policy, Faculty of Economics, Istanbul University, Istanbul, Turkey. \\ ORCID: 0000-0002-4928-8303 / e-mail: mzdincer@istanbul.edu.tr
}

\begin{tabular}{l} 
KEYWORDS \\
\hline Emotional Dissonance \\
Quality of work life \\
Life Satisfaction \\
Burnout \\
Tour Guides
\end{tabular}

\section{Introduction}

The labor-intensive nature of tourism services implies an intensive interaction between tourism employees and customers (Deery \& Jago, 2009). Although it could be often stressful (Acar \& Erkan, 2018), employees are usually expected to regulate their emotions according to the display rules desired by their organizations (Pizam, 2004). These desirable emotions may not necessarily be matching with employees' truly felt emotions. This surface acting is referred to as emotional dissonance whereas employees' effort to truly feel the emotions desired by the employer is referred to as deep acting or emotional effort. Both cases are conceptualized in the emotional labor theory, which suggests that employees manage their emotions to abide to the employers' rule of display. Previous research addresses the antecedents and consequences of emotional labor (Brotheridge \& Grandey, 2002; Brotheridge \& Lee, 2003; Hur et al., 2013; Karatepe, 2011; Cropanzano et al., 2003; Xu et al., 2020). However, comprehensive modeling of the emotional labor construct with other organizational and psychological variables in the specific context of tour guides is lacking.

\footnotetext{
${ }^{1}$ This paper is based on Derya Demirdelen Alrawadieh's Ph.D. dissertation.
}

Closely related to emotional labor, the wellbeing of employees in tourism and hospitality has received increasing intention (Alrawadieh et al., 2021). While some research draws on emotional labor theory to understand employees' well-being, a major drawback, as noted by Alrawadieh et al (2020) is that previous research assumes tourism professions homogeneous. With these thoughts in mind, the present study proposes a conceptual model establishing linkages between emotional dissonance, emotional effort, quality of work life, life satisfaction, organizational support, burnout, and turnover intention (Figure 1). The model was tested using data from Turkish professional tour guides.

The study contributes to the emotional labor and well-being theories. Specifically, the study examines how emotional labor affects the professional and personal lives of tourism employees (McGinley \& Wei, 2018). The study also adds to the limited research delving into the well-being of tour guides (Wong \& Wang, 2009; Mackenzie \& Kerr, 2013; Alrawadieh, 2020; Alrawadieh et al., 2021).

${ }^{\star}$ Corresponding Author.

Received 12.05.2021; Received in revised form 16.06.2021; Accepted 18.06.2021 This article is licensed under a Creative Commons Attribution 4.0 International License. e-ISSN: 2687 - 3737 / (c) 2021 The Authors. Published by Anadolu University. 


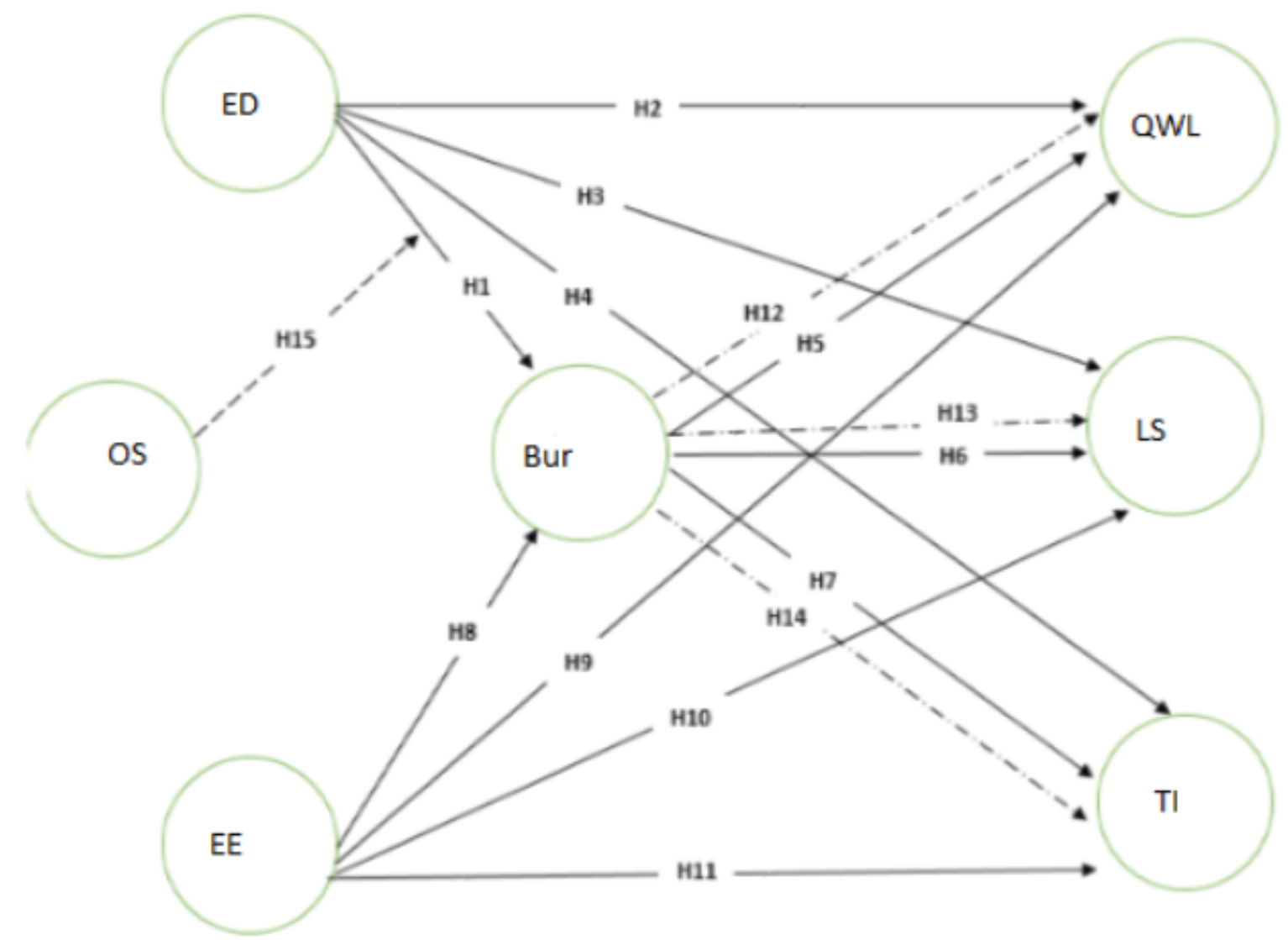

Figure 1. Conceptual Framework

\section{Literature Review}

\subsection{Emotional Labor in Tourism Services}

Emotional labor is defined as "the management of feeling to create a publicly observable facial and bodily display" (Hochschild, 1983: 7). Employees are often confronted with the situation where they have to suppress their true feelings and show emotions desired by the employer or organization. Emotional dissonance or surface role-playing occurs when the emotions displayed do not match the emotions that are felt (Wong \& Wang, 2009). Emotional dissonance has received considerable attention in tourism research (Karatepe \& Aleshinloye, 2009; Karatepe, 2011; Hur et al., 2013; Karatepe \& Choubtarash, 2014; Hofmann \& Stokburger-Sauer, 2017; Alrawadieh et al., 2020). Another important dimension of emotional labor is emotional effort. Unlike emotional dissonance, emotional effort or deep acting is defined as an effort to change one's own emotions (Cropanzano et al., 2003).

The core of emotional labor lies in the emotion regulation process. Display rules, which require employees to regulate and control their emotions are determined by businesses or employers (Diefendorff \& Gosserand, 2003). While emotional labor may be viewed as a burden and thus an undesirable situation, it may have either positive or negative consequences depending on the emotion regulation style. For instance, previous research notes that while experiencing emotional dissonance may result in negative effects, emotional effort may bring about positive outcomes (Brotheridge \& Grandey, 2002;
Brotheridge \& Lee, 2003; Martínez-Iñigo et al., 2007; Karatepe, 2011; Hur et al., 2013). Thus, emotional labor dimensions may have different outcomes.

\subsection{Well-being of Tourism Employees}

Well-being is a complex concept and there exists no definition that is accepted by all (Brown \& Westaway, 2011). Life satisfaction and happiness are often used to describe well-being (Eger \& Maridal, 2015; Alrawadieh \& Demirdelen Alrawadieh, 2020). In positive psychology, hedonism and eudaimonism are key concepts employed to understand wellbeing. Hedonism is conceptualized as the existence of positive affect and the avoidance of negative affect (Kahneman et al., 1999) whereas eudaimonism equates happiness with the human ability to pursue complex goals (Delle Fave et al., 2011). Tourism is intertwined with well-being. A large body of research highlights this intersection from the tourist side as well as the local community side (Woo, Kim, \& Uysal, 2015; Nawijn \& Filep, 2016; Knobloch, Robertson \& Aitken, 2017; Saayman et al., 2018). Recently, however, the well-being of tourism and hospitality employees has gained some attention (Alrawadieh \& Demirdelen Alrawadieh, 2020).

\subsection{Organizational Support in Tourism Workplaces}

Perceived organizational support is defined as the extent to which organizations attribute importance to their employees and care about their well-being (Eisenberger et al., 1986). From a social exchange theory, organizational support may 
be viewed as a win-win relationship (DeConinck, 2010). Some research delves into the relationship between organizational support and emotional labor (Wen, Huang, \& Hou, 2019; Wang, 2020; Mastracci \& Adams, 2020). Employees' perception of organizational support is argued to play a critical role in reducing workplace stress (Kang et al., 2010) and burnout (Karatepe, 2011). Specifically, some studies employees' emotional labor as a moderator variable affecting the relationship between emotional labor and other organizational variables. For instance, Wen, Huang and Hou (2019) found that perceived organizational support moderates the relationship between employees' deep acting and job satisfaction.

\section{Hypotheses Development}

Surface acting by employees may increase their burnout levels (Van Dijk \& Brown 2006; Hwa, 2012). Brotheridge and Grandey (2002) found that surface acting is positively associated with depersonalization, which is a dimension of burnout. Hwa (2012) suggested that surface acting by hotel staff is directly related to their burnout levels. Similar findings are reported in other studies (Karatepe, 2011; Kim \& Back, 2012). In the context of tour guiding, there exist conflicting findings. While Kaya and Özhan (2012) could not find a relationship between surface acting and burnout in their study, Akdu and Akdu (2016) concluded that there is a positive relationship between emotional labor and burnout. Overall, there exists considerable empirical research showing that employees' surface acting may result in greater levels of burnout. Therefore, the following hypothesis was proposed:

H1: The emotional dissonance experienced by tour guides has a positive and significant effect on burnout.

A considerable body of research suggests that emotional dissonance can negatively affect job satisfaction (Gürsoy, Boylu, \& Avcl, 2011; Kim et al., 2012; Chen et al., 2012). For tour guides who usually have more intense interaction with tourists, suppressing real emotions or faking emotions can be stressful (Alrawadieh et al., 2020). In this context, the following hypothesis is proposed:

H2: The emotional dissonance experienced by tour guides has a negative and significant effect on the quality of work life.

While previous studies (e.g., Hofmann \& Stokburger-Sauer, 2017) address the negative effects of emotional dissonance on tourism employees' professional life, very few studies examine the consequences of emotional dissonance on employees' personal life (McGinley \& Wei, 2018; Alrawadieh et al., 2020). Generally speaking, individuals' display of emotions that they do not really feel can harm their psychological well-being (Cropanzano et al.,
2003). Surface role-play requires effort and may cause depletion of psychological resources thus threatening individuals' well-being (MartínezIñigo et al., 2007). In a study on tour leaders, role display is argued to poses a danger to the well-being of employees. However, Alrawadieh et al.'s (2020) study could not confirm this relationship. Although they provided a possible explanation for their unexpected results, they called for more research into this issue. In the light of this information, the following hypothesis is proposed:

H3: The emotional dissonance experienced by tour guides has a negative and significant effect on life satisfaction.

Emotional dissonance may also encourage turnover intention. In their study of hotel employees, Karatepe and Aleshinloye (2009) found a positive and significant relationship between emotional dissonance and turnover intention. Interestingly, employing turnover intention is rarely encountered in research related to tour guides. This may be because tour guides may be free-lancers thus discouraging research modelling turnover. In their qualitative research, Wong and Wang (2009) found that role display was exhausting for tour leaders therefore some of them were unsatisfied with their profession and planned to leave. Based on this discussion, the following hypothesis is developed:

H4: The emotional dissonance experienced by tour guides has a positive and significant effect on turnover intention.

Defined as a source of organizational stress, burnout can seriously harm the quality of work life of employees. Due to the nature of tourism services, face-to-face communication is experienced intensively, between both employees and customers. Therefore, burnout is acknowledged as one of the most common problems faced by those working in the tourism sector (Cheng \& Yi, 2018; Koo et al., 2020; Yetgin \& Benligiray, 2019). In addition, burnout can seriously affect individuals' personal life. Studies conducted in the field of tourism indicate that the burnout levels of employees negatively affect their life satisfaction (Chen \& Kao, 2012). In their study on hotel staff, Şahin and Şad (2018) concluded that all dimensions of burnout have a negative impact on life satisfaction. Previous research also indicates that burnout is a key antecedent for turnover intention (Lu \& Gursoy, 2016; Han et al., 2016; Chiang \& Liu, 2017). Based on this discussion, the following hypotheses were developed:

H5: Burnout experienced by tour guides has a negative and significant effect on their quality of work life.

H6: Burnout experienced by tour guides has 
a negative and significant effect on their life satisfaction.

H7: Burnout experienced by tour guides has a positive and significant effect on turnover intention.

Unlike emotional dissonance, studies indicate that emotional effort can have positive impacts. For instance, emotional effort is argued to reduce burnout (Hwa, 2012). Lee et al.'s (2018) study on flight personnel noted that deep acting was inversely proportional to depersonalization, one dimension of burnout. Not only does not emotional effort cause negative effects at professional and personal levels (Martínez-Iñigo et al., 2007), but it also may have positive effects (Allen et al., 2010; $\mathrm{Xu}$ et al., 2020). It is stated that emotional effort increases job satisfaction and decreases stress and turnover intention (Xu et al., 2020). In their study on hotel staff, Chu et al. (2012) confirmed that there is a positive effect between emotional effort and job satisfaction. In other words, emotional effort leads to positive outcomes for employees. Therefore, we propose the following hypotheses:

H8: The emotional effort of tour guides has a negative and significant effect on burnout

H9: The emotional effort of tour guides has a significant effect on their quality of work life.

H10: The emotional effort of tour guides has a significant effect on their life satisfaction.

H11: The emotional effort of tourist guides has a significant effect on their turnover intention.

While it is important to understand the direct relationships between emotional dissonance and quality of work life, life satisfaction, and turnover intention, it is also necessary to address the indirect effects of emotional dissonance given the complexity of human emotions. In this study, we propose that burnout can mediate the relationships between emotional dissonance on the one hand, and quality of work life, life satisfaction, and turnover intention on the other hand. Several studies have examined the mediating role of burnout (Chen \& Kao, 2012; Lv, $\mathrm{Xu}, \& \mathrm{Ji}, 2012$; Cheng \& Yi, 2018). For example, Kim and Back (2012) found that emotional dissonance affects job satisfaction through burnout. In their study on hotel staff, Lv, Xu, and Ji (2012) concluded that emotional labor affects the turnover intention through emotional exhaustion as a key dimension of burnout. However, there are very limited studies on the mediating role of burnout in the relationships between emotional dissonance on the one hand, and quality of work life, life satisfaction, and turnover intention. Therefore, the following hypotheses are proposed:
H12: Burnout mediates the relationship between emotional dissonance and the quality of work life.

\section{H13: Burnout mediates the relationship between} emotional dissonance and life satisfaction.

\section{H14: Burnout mediates the relationship between} emotional dissonance and turnover intention.

Tourism employees are expected to display positive attitudes and emotions even under difficult conditions. While this situation provides benefits for the organization, it may cause adverse impacts on employees' well-being. In this sense, the organizational support that businesses provide to their employees may be of significant importance. Studies show that perceived organizational support reduces stress from work (Walters \& Raybould, 2007; Kang et al., 2010). In their meta-analysis study, Rhoades and Eisenberger (2002) stated that organizational support could create a positive atmosphere in the workplace. In a recent metaanalysis study in the field of tourism and hospitality, $\mathrm{Xu}$ et al. (2020) demonstrated the positive effects of organizational support in the workplace on emotional labor. Thus, we propose the following hypothesis

H15: Organizational support moderates (reduces) the impact of emotional dissonance on burnout.

\section{Methodology}

To measure the constructs employed in the model, multiple-item measures from previous literature were used. The Hospitality Emotional Labor Scale (HELS) developed by Chu and Murrmann (2006) was used to measure the key two dimensions of emotional labor; emotional dissonance (11 items) and emotional effort (8 items). Burnout was measured using 6 items from Babakus, Yavas, and Ashill, (2009). Six items were also adopted from Shanock and Eisenberger (2006) to measure perceived organizational support. The quality of work life was operationalized using 16 items from Sirgy et al. (2001). Although the original scale has 7 sub-dimension, in the present study, the scale was employed as unidimensional (Alrawadieh et al., 2020). Life satisfaction was measured using a 5-item scale developed by Diener et al. (1985). Finally, 3 items were adopted from Singh, Verbeke, and Rhoads (1996) to measure the turnover intention.

The present study used a self-administered questionnaire to collect data. In order to ensure the comprehensibility of the questions, the questionnaire was filled by and pre-tested on 30 four-year students from the tourist guidance department of a major university in Istanbul. Following this pilot study, no significant changes were made to the questionnaire. Content validity was also ensured using expert panel 
feedback (Dolnicar, 2020). Six experts (3 tourism academicians and 3 active tourist guides) were asked to examine the questionnaire and provide feedback on the clarity of the content. At this stage, some minimal changes were made. For example, the word "organization" used in the organizational support scale was changed to "travel agency" to fit the context of the study. The final version of the questionnaire consists of two sections; the first section aimed to collect demographic data about the participants, the second section aimed to measure the variables used in the model. Filling the questionnaire took around 12 minutes. The data collection process started on February 4, 2020, and was completed on 13 May 2020.

After the pilot study, the final version of the questionnaire was determined. Given that there were only 8897 active tour guides in Turkey, the data collection was inherently associated with some difficulty. To reach out to participants, all tour guide chambers in Turkey (13 chambers) were contacted and support was sought. Although an infield study was planned to reach the participants in various attraction centers of Istanbul (e.g., historical downtown, Grand Bazaar), this fieldwork was not possible due to the Covid-19. The limited access to participants was also overcome by relying on the snowball method. Participants were qualified to take part in the study as they were officially licensed tour guides who have worked as professional tourist guide for at least one year. At the end of the data collection, 301 usable questionnaires were obtained. The sample size adequacy was ensured using G*Power (Faul et al., 2009) whereby 301 exceeds the minimum required sample size $(134$ cases) to achieve a minimum power of 0.80 at the 95 percent confidence level. The demographic profile is presented in Table 1. Finally, the data were analyzed using PLS-SEM.

\section{Findings and Discussion}

\subsection{Measurement Model Assessment}

Before testing the proposed model and the hypotheses, it is necessary to ensure the reliability and validity of the measurement model. Reliability is assessed based on the factor loadings, Composite Reliability (CR) values, Cronbach's Alpha ( $\alpha$ ), and rho-A values. While factor loadings should be above 0.7 (Hair et al., 2017; Ali et al., 2018), items with factor loadings between 0.5 and 0.7 can be kept if AVE and convergent validity are not affected (e.g. Hair et al., 2017; Rasoolimanesh et al., 2017). As shown in Table 2, Composite Reliability (CR), Cronbach Alpha, and rho-A values are all above 0.7 (Hair et al., 2017; Ali et al., 2018). After removing $5 \mathrm{ED}, 4 \mathrm{EE}$, and 7 QWL, the CR values are between 0.86 and 0.92 , the Cronbach Alpha values are between 0.78 and 0.89 , and the rho-A values are between 0.79 and 0.90 Therefore, the reliability of the measurement model is confirmed.

Validity is assessed by examining the convergent
Table 1. Demographic Profiles of Participants

\begin{tabular}{|c|c|c|}
\hline Variables & $\mathbf{N}=(\mathbf{3 0 1})$ & Percentage \\
\hline \multicolumn{3}{|l|}{ Gender } \\
\hline Female & 105 & 34,9 \\
\hline Male & 196 & 65,1 \\
\hline \multicolumn{3}{|l|}{ Age } \\
\hline $18-24$ & 10 & 3,3 \\
\hline $25-34$ & 112 & 37,2 \\
\hline $35-44$ & 85 & 28,3 \\
\hline $45-54$ & 69 & 22,9 \\
\hline 55 and over & 25 & 8,3 \\
\hline \multicolumn{3}{|l|}{ Marital status } \\
\hline Single & 137 & 45,5 \\
\hline Married & 155 & 51,5 \\
\hline Other & 9 & 3,0 \\
\hline \multicolumn{3}{|l|}{ Education } \\
\hline High school or less & 6 & 2,0 \\
\hline College diploma & 38 & 12,6 \\
\hline Bachelor's degree & 161 & 53,5 \\
\hline Master's degree & 67 & 22,3 \\
\hline Ph.D. & 29 & 9,6 \\
\hline \multicolumn{3}{|l|}{ Work experience } \\
\hline Less than 2 years & 63 & 20,9 \\
\hline 3-6 years & 61 & 20,3 \\
\hline $7-10$ years & 51 & 16,9 \\
\hline $11-15$ years & 59 & 19,6 \\
\hline 16 years and over & 67 & 22,3 \\
\hline \multicolumn{3}{|l|}{ Licensed language* } \\
\hline English & 231 & 56,9 \\
\hline Spanish & 29 & 7,1 \\
\hline German & 27 & 6,7 \\
\hline Others & 119 & 29,3 \\
\hline
\end{tabular}

*The number of licensed languages (406) is larger than the samr

validity and discriminant validity of the constructs. The basic rule in ensuring convergent validity is that the average explained variance (AVE) value for each of the variables in the model should be higher than 0.5. As seen in Table 3, AVE values are between 0.5 and 0.76 . Thus, convergent validity is ensured. For discriminant validity, two criteria are evaluated. Fornell-Larcker criterion and Hetero-Trait-MonoTrait (HTMT) value (Henseler et al., 2015; Voorhees et al., 2016). According to the Fornell-Larcker criterion, the square root of the average explained variance (AVE) values should be greater than the correlations with the other variables (Hair et al., 2017). According to the Heterotrait-Monotrait (HTMT) criterion, the HTMT value should be lower than 85 (Henseler et al., 2015). As seen in Table 3, the discriminant validity has been confirmed according to both approaches.

\subsection{Structural Model Assessment}

After confirming the reliability and validity of the scales used in the model, the structural model was assessed. The Bootstrap 500 method was applied to test the hypothesized relationships. As shown in Table 4, nine out of the eleven direct hypotheses proposed were confirmed. Emotional dissonance was found to have a positive and significant effect on burnout $(\beta=0.41, p<0.01)$ thus supporting H1. The results also show that, while emotional dissonance has a negative and significant effect on 
Table 2. Validity and Reliability

\begin{tabular}{|c|c|c|c|c|c|}
\hline Construct & $\begin{array}{l}\text { Fac. } \\
\text { loadings }\end{array}$ & $\begin{array}{c}\text { Cronbach } \\
(\alpha)\end{array}$ & Rho_A & $\mathbf{C R}$ & AVE \\
\hline Emotional Dissonance & & 0.809 & 0.812 & 0.863 & 0.513 \\
\hline $\begin{array}{l}\text { ED1: I fake a good mood when interacting with } \\
\text { tourists. }\end{array}$ & 0.682 & & & & \\
\hline $\begin{array}{l}\text { ED2: I fake the emotions I show when dealing } \\
\text { with tourists. }\end{array}$ & 0.783 & & & & \\
\hline $\begin{array}{l}\text { ED3: I put on a mask in order to express the right } \\
\text { emotions for my job. }\end{array}$ & 0.809 & & & & \\
\hline $\begin{array}{l}\text { ED4*: The emotions I show to tourists match what I } \\
\text { truly feel. }\end{array}$ & 0.698 & & & & \\
\hline ED7: My interactions with tourists are very robotic. & 0.671 & & & & \\
\hline $\begin{array}{l}\text { ED10*: I actually feel the emotions that I need to } \\
\text { show to do my job well. }\end{array}$ & 0.639 & & & & \\
\hline Emotional Effort & & 0.784 & 0.796 & 0.860 & 0.606 \\
\hline $\begin{array}{l}\text { EE3: I think of pleasant things when I am getting } \\
\text { ready for tour. }\end{array}$ & 0.766 & & & & \\
\hline $\begin{array}{l}\text { EE5: When getting ready for tour, I tell myself that I } \\
\text { am going to have a good day. }\end{array}$ & 0.846 & & & & \\
\hline $\begin{array}{l}\text { EE6: I try to actually experience the emotions that I } \\
\text { must show when interacting with tourists. }\end{array}$ & 0.756 & & & & \\
\hline $\begin{array}{l}\text { EE7: I work at calling up the feelings I need to show } \\
\text { to tourists. }\end{array}$ & 0.740 & & & & \\
\hline Organizational Support & & 0.895 & 0.900 & 0.920 & 0.657 \\
\hline $\begin{array}{l}\text { OS1: The travel agency values my contribution to its } \\
\text { well-being. }\end{array}$ & 0.753 & & & & \\
\hline $\begin{array}{l}\text { OS 2: The travel agency strongly considers my goals } \\
\text { and values. }\end{array}$ & 0.855 & & & & \\
\hline $\begin{array}{l}\text { OS 3: The travel agency really cares about my well- } \\
\text { being. }\end{array}$ & 0.859 & & & & \\
\hline $\begin{array}{l}\text { OS 4: The travel agency is willing to help me when } \\
\text { I need a special favor. }\end{array}$ & 0.825 & & & & \\
\hline $\begin{array}{l}\text { OS } 5^{*} \text { : The travel agency shows very little concern } \\
\text { for me. }\end{array}$ & 0.808 & & & & \\
\hline $\begin{array}{l}\text { OS 6: The travel agency takes pride in my } \\
\text { accomplishments at work. }\end{array}$ & 0.757 & & & & \\
\hline Burnout & & 0.824 & 0.833 & 0.871 & 0.531 \\
\hline Bur1: I feel emotionally drained from my work. & 0.727 & & & & \\
\hline Bur2: I feel used up at the end of the workday. & 0.767 & & & & \\
\hline Bur3: I feel burned out from my work. & 0.819 & & & & \\
\hline $\begin{array}{l}\text { Bur4: I feel I treat some customers as if they are } \\
\text { impersonal 'objects'. }\end{array}$ & 0.684 & & & & \\
\hline $\begin{array}{l}\text { Bur5: I feel I have become uncaring toward people } \\
\text { since I took this job. }\end{array}$ & 0.683 & & & & \\
\hline $\begin{array}{l}\text { Bur6: I worry that this job is hardening me } \\
\text { emotionally. }\end{array}$ & 0.683 & & & & \\
\hline Quality of Work Life & & 0.875 & 0.881 & 0.900 & 0.502 \\
\hline QWL6: My job does well for my family. & 0.600 & & & & \\
\hline QWL9: I feel appreciated at my work. & 0.703 & & & & \\
\hline $\begin{array}{l}\text { QWL10: People at my travel agency and/or within } \\
\text { my profession respect me as a professional and an } \\
\text { expert in my field of work. }\end{array}$ & 0.685 & & & & \\
\hline $\begin{array}{l}\text { QWL11: I feel that my job allows me to realize my } \\
\text { full potential. }\end{array}$ & 0.769 & & & & \\
\hline $\begin{array}{l}\text { QWL12: I feel that I am realizing my potential as an } \\
\text { expert in my line of work }\end{array}$ & 0.755 & & & & \\
\hline $\begin{array}{l}\text { QWL13: I feel that I'm always learning new things } \\
\text { that help do my job better. }\end{array}$ & 0.653 & & & & \\
\hline $\begin{array}{l}\text { QWL14: This job allows me to sharpen my } \\
\text { professional skills. }\end{array}$ & 0.773 & & & & \\
\hline $\begin{array}{l}\text { QWL15: There is a lot of creativity involved in my } \\
\text { job. }\end{array}$ & 0.703 & & & & \\
\hline $\begin{array}{l}\text { QWL16: My job helps me develop my creativity } \\
\text { outside of work. }\end{array}$ & 0.720 & & & & \\
\hline Life Satisfaction & & 0.849 & 0.870 & 0.892 & 0.624 \\
\hline LS1: In most ways my life is close to my ideal. & 0.689 & & & & \\
\hline LS2: The conditions of my life are excellent. & 0.826 & & & & \\
\hline LS3: I am satisfied with my life. & 0.862 & & & & \\
\hline $\begin{array}{l}\text { LS4: So far I have gotten the important things I want } \\
\text { in life. }\end{array}$ & 0.811 & & & & \\
\hline $\begin{array}{l}\text { LS5: If I could live my life over, I would change } \\
\text { almost nothing. }\end{array}$ & 0.749 & & & & \\
\hline Turnover Intention & & 0.844 & 0.865 & 0.905 & 0.761 \\
\hline $\begin{array}{l}\text { TI1: It is likely that I will actively look for a new job } \\
\text { next year. }\end{array}$ & 0.819 & & & & \\
\hline TI2: I often think about quitting. & 0.882 & & & & \\
\hline TI3: I will probably look for a new job next year. & 0.913 & & & & \\
\hline
\end{tabular}


Table 3. Discriminant Analysis

\begin{tabular}{|c|c|c|c|c|c|c|c|}
\hline \multicolumn{8}{|c|}{ Fornell-Larcker Criterion } \\
\hline Construct & 1 & 2 & 3 & 4 & 5 & 6 & 7 \\
\hline Burnout & 0.729 & & & & & & \\
\hline Emotional dissonance & 0.526 & 0.716 & & & & & \\
\hline Emotional effort & -0.320 & -0.351 & 0.778 & & & & \\
\hline Life satisfaction & -0.446 & -0.336 & 0.345 & 0.790 & & & \\
\hline Organizational support & -0.361 & -0.388 & 0.320 & 0.487 & 0.811 & & \\
\hline Quality of work life & -0.494 & -0.421 & 0.576 & 0.636 & 0.624 & 0.709 & \\
\hline Turnover intention & 0.503 & 0.378 & -0.113 & -0.495 & -0.383 & -0.420 & 0.872 \\
\hline \multicolumn{8}{|c|}{ Heterotrait-Monotrait (HTMT) Criterion } \\
\hline & 1 & 2 & 3 & 4 & 5 & 6 & 7 \\
\hline \multicolumn{8}{|l|}{ Burnout } \\
\hline Emotional dissonance & 0.655 & & & & & & \\
\hline Emotional effort & 0.398 & 0.422 & & & & & \\
\hline Life satisfaction & 0.499 & 0.383 & 0.415 & & & & \\
\hline Organizational support & 0.402 & 0.453 & 0.374 & 0.543 & & & \\
\hline Quality of work life & 0.565 & 0.487 & 0.673 & 0.730 & 0.715 & & \\
\hline Turnover intention & 0.578 & 0.451 & 0.141 & 0.573 & 0.443 & 0.495 & \\
\hline
\end{tabular}

the quality of work life $(\beta=-0.11, p<0.05)$, its effect on life satisfaction was not confirmed $(\beta=-0.09$, $p>$ $0.05)$. Hence, $\mathrm{H} 2$ was accepted while $\mathrm{H} 3$ was not supported. In addition, the analysis results confirm the relationship between emotional dissonance and turnover intention $(\beta=0.18, p<0.01)$ thus supporting H4.

As expected, burnout appears to have a negative and significant effect on the quality of work life $(\beta=$ $-0.29, \mathrm{p}<0.01)$ and life satisfaction $(\beta=0.33, \mathrm{p}<0.01)$. Moreover, burnout has a positive and significant effect on turnover intention $(\beta=0.44, \mathrm{p}<0.01)$. Therefore, H5, H6, and $\mathrm{H7}$ are supported. The results also show that while emotional effort performed by tour guides decreases their burnout levels $(\beta=-0.12$, $p<0.05$ ), It appears to enhance their quality of work life $(\beta=0.44, p<0.01)$ and life satisfaction $(\beta=0.20$, $\mathrm{p}<0.01$ ). Hence, H8, H9 and H10 are supported. The effect of emotional effort on the turnover intention was not significant and H11 was not supported.

\subsection{Assessment of the Mediating Effects}

According to the proposed model (Figure 1), burnout mediates the relationship between emotional dissonance and emotional effort on the one hand, and quality of work life, life satisfaction, and turnover intention on the other hand. According to Zhao et al., (2010), in order to accept the hypotheses

Table 4. Hypothesis Tests (Direct effects)

\begin{tabular}{lllllc}
\hline Hypothesis & \multicolumn{1}{c}{ Direction } & Beta & T-value & P value & Result \\
& & & & & \\
H1 & Emotional Dissonance $\rightarrow$ Burnout & 0.410 & $8.491^{* *}$ & 0.000 & Supported \\
H2 & Emotional Dissonance $\rightarrow$ Quality of Work Life & -0.111 & $2.106^{*}$ & 0.036 & Supported \\
H3 & Emotional Dissonance $\rightarrow$ Life Satisfaction & -0.088 & 1.336 & 0.182 & Not supported \\
H4 & Emotional Dissonance $\rightarrow$ Turnover Intention & 0.179 & $2.677^{* *}$ & 0.008 & Supported \\
H5 & Burnout $\rightarrow$ Quality of Work Life & -0.294 & $5.396^{* *}$ & 0.000 & Supported \\
H6 & Burnout $\rightarrow$ Life Satisfaction & -0.333 & $4.848^{* *}$ & 0.000 & Supported \\
H7 & Burnout $\rightarrow$ Turnover Intention & 0.437 & $6.665^{* *}$ & 0.000 & Supported \\
H8 & Emotional Effort $\rightarrow$ Burnout & -0.116 & $2.022^{*}$ & 0.044 & Supported \\
H9 & Emotional Effort $\rightarrow$ Quality of Work Life & 0.443 & $7.859^{* *}$ & 0.000 & Supported \\
H10 & Emotional Effort $\rightarrow$ Life Satisfaction & 0.208 & $3.452^{* *}$ & 0.001 & Supported \\
H11 & Emotional Effort $\rightarrow$ Turnover Intention & 0.090 & 1.450 & 0.148 & Not supported
\end{tabular}

Table 5. Hypothesis Tests (Indirect effects)

\begin{tabular}{llccccc}
\hline Hypothesis & \multicolumn{1}{c}{ Direction } & Beta & T-value & $\begin{array}{c}\text { P } \\
\text { value }\end{array}$ & $\begin{array}{l}\text { Confidence } \\
\text { interval }\end{array}$ & Result \\
H12 & $\begin{array}{l}\text { Emotional Dissonance } \rightarrow \\
\text { Burnout } \rightarrow \text { Quality of } \\
\text { Work Life }\end{array}$ & -0.120 & $4.465^{* *}$ & 0.000 & {$[-0.176-0.072]$} & Supported \\
H13 & $\begin{array}{l}\text { Emotional Dissonance } \rightarrow \\
\text { Burnout } \rightarrow \text { Life } \\
\text { Satisfaction }\end{array}$ & -0.136 & $3.984^{* *}$ & 0.000 & {$[-0.211-0.077]$} & Supported \\
H14 & $\begin{array}{l}\text { Emotional Dissonance } \rightarrow \\
\text { Burnout } \rightarrow \text { Turnover } \\
\text { Intention }\end{array}$ & 0.179 & $4.733^{* *}$ & 0.000 & {$[0.112-0.257]$} & Supported \\
& & & & & & \\
\hline
\end{tabular}


Table 6. Assessment of the Moderating Effect

\begin{tabular}{clcccc}
\hline Hypothesis & \multicolumn{1}{c}{ Interaction Term } & Beta & $\begin{array}{c}\text { T- } \\
\text { value }\end{array}$ & $\begin{array}{c}\text { P } \\
\text { value }\end{array}$ & Result \\
H15 & $\begin{array}{l}\text { Organizational support* Emotional } \\
\text { Dissonance } \rightarrow \text { Burnout }\end{array}$ & -0.056 & 1.278 & 0.202 & Not supported \\
\hline
\end{tabular}

suggesting the mediation effect, the indirect effects tested with the bootstrap technique should be significant and the confidence interval should not contain zero. As shown in Table 5, burnout appears to mediate the relationships between emotional dissonance and quality of work life $(\beta=-0.12$, $p$ $<0.01$ ), emotional dissonance and life satisfaction $(\beta=-0.14, p<0.01)$, and emotional dissonance and turnover intention $(\beta=0.18, \mathrm{p}<0.01)$. Hence, $\mathrm{H} 12$, $\mathrm{H} 13$ and $\mathrm{H} 14$ are supported. The indirect effects provide interesting findings, specifically, while there was no evidence that emotional dissonance directly affects life satisfaction (H3), this relationship was confirmed when mediated by burnout. In other words, emotional dissonance experienced by tour guides increases their burnout levels and consequently decreases their life satisfaction.

\subsection{Assessment of the Moderating Effect}

The proposed model suggests that organizational support can moderate the impact of emotional dissonance on burnout. As shown in Table 6, against expectation, organizational support, although it reduces the positive effect of emotional dissonance on burnout, this effect is not significant $(\beta=-0.06, P$ $>0.05$ ).

\section{Conclusion and Implications}

The study proposed a theoretical model linking emotional labor with quality of work life, life satisfaction, organizational support, burnout, and turnover intention. The model was tested using data from Turkish professional tour guides. The study makes several theoretical implications and suggests various practical implications.

\subsection{Theoretical Implications}

This study's results support the views that the dimensions of emotional labor can have different effects (Brotheridge \& Grandey, 2002; Cropanzano et al., 2003; Brotheridge \& Lee, 2003; Karatepe, 2011; Hur et al., 2013; Xu et al., 2020). Specifically, findings suggest that emotional dissonance increases burnout and turnover intention and decreases quality of work life. However, the emotional effort is found to be associated with decreased burnout and enhanced quality of work life and life satisfaction. Previous research also shows that while emotional dissonance increases burnout, emotional effort decreases it (Brotheridge \& Grandey, 2002; Brotheridge \& Lee, 2003; Hwa, 2012; Hur et al., 2013). In line with Xu et al. (2020), the study also shows that emotional dissonance harms tour guides' quality of life and triggers turnover intention. Interestingly, the proposed negative impact of emotional dissonance on life satisfaction was not confirmed. Alrawadieh et al. (2020) also fail to confirm this relationship.

The study confirms the mediating role of burnout on the relationship between emotional dissonance and quality of work life, as well as the relationship between emotional dissonance and life satisfaction. Therefore, the study provides empirical evidence into the indirect effects of emotional dissonance on organizational and personal wellbeing.

Finally, the study results fail to confirm the moderating role of organizational support on the relationship between emotional dissonance and burnout. This is in contrast with previous research confirming the moderating role of organizational support in several contexts. For example, Hur et al. (2013) found that organizational support has a moderating effect on the relationship between emotional dissonance and emotional exhaustion. Our study's failure to support the moderating effect of organizational support may be justified by the fact that tour guides are likely to work on a freelance basis representing more than one tour operator (Cetin \& Yarcan, 2017). Our findings, however, partially intersect with the findings of Karatepe (2011). According to their study, organizational support does not moderate the impact of emotional dissonance on exhaustion, but it can moderate the effect on disengagement, which is one of the dimensions of burnout.

The study makes several theoretical contributions. First, the study responds to recent calls for research examining how emotional labor affects the professional and personal lives of tourism employees (e.g., McGinley \& Wei 2018). The study also contributes to the limited body of literature addressing the well-being of tour guides (Wong \& Wang, 2009; Mackenzie \& Kerr, 2013; Alrawadieh, 2020; Alrawadieh et al., 2021). The present study also contributes by modelling organizational support, a construct rarely addressed in tourism research.

\subsection{Managerial Implications}

Based on the findings, the study suggests several implications for stakeholders in the travel industry, especially travel agencies and tour operators. First, the study findings show that the emotional dissonance experienced by tour guides can increase their burnout, decrease their quality of work life, and enhance their intention to change their profession. However, the findings suggest that the emotional effort of tour guides may reduce burnout levels, enhance their quality of work life, and life satisfaction. Therefore, the emotional dissonance seems to have an adverse impact on tour guides' professional and personal lives whereas emotional effort may have 
positive outcomes. In this sense, tour guides may be encouraged to deep act instead of faking emotions. For example, tour guides chambers and unions may organize seminars and train their members about emotion regulation. These training programs and seminars should focus on communicating the benefits of deep role play and suggesting strategies on how to switch from surface role-playing to deep role-playing.

The findings of the study failed to confirm the expected moderating role of organizational support on the relationship between emotional dissonance and burnout. It appears that support from travel agencies or tour operators has a minimal role in eliminating the negative effects of emotional dissonance. While this should not lead to underestimating the value of organizational support, it seems that when employees experience emotional dissonance, it is unlikely that support from travel agencies or tour operators would reduce the negative consequences of emotional dissonance.

\subsection{Limitations and Directions for Future Research}

The study concludes with some implications and avenues for further research. The data was collected from tour guides and thus the results may not apply to all tourism employees. Another important limitation of the study is that the data collection process coincided with the Covid-19 pandemic. Therefore, this study may need to be revalidated after the pandemic is over. Interestingly, the expected moderating role of organizational support in the model was not confirmed. Further research may look into other moderating variables including perceived social support (e.g., support by family members and friends). The model can also be expanded by employing personality traits. Finally, the negative effects of emotional maladjustment were revealed in the study.

\section{References}

Acar, A. \& Erkan, M. (2018). The Effects of Quality of Work Life On Burnout Syndrome: A Study On Hospitality Industry. Journal of Tourismology, 4(1), 1-19.

Akdu, U. \& Akdu, S. (2016). Duygusal Emek Ve İş Stresinin Tükenmişlik Üzerindeki Etkileri: Profesyonel Turist Rehberleri Üzerinde Bir Araştirma. Journal of International Social Research, 9(47). 1142-1152.

Ali, F., Rasoolimanesh, S. M., Sarstedt, M., Ringle, C. M., \& Ryu, K. (2018). An assessment of the use of partial least squares structural equation modeling (PLSSEM) in hospitality research. International Journal of Contemporary Hospitality Management.

Allen, J. A., Pugh, S. D., Grandey, A. A., \& Groth, M. (2010). Following display rules in good or bad faith? Customer orientation as a moderator of the display rule-emotional labor relationship. Human Performance, 23(2), 101-115.

Alrawadieh, Z., \& Demirdelen Alrawadieh, D. (2020). Sexual harassment and wellbeing in tourism workplaces: The perspectives of female tour guides. In Vizcaino-Suárez, P., Jeffrey, H. \& Eger, C. (eds.), Tourism and Gender-
Based Violence - Challenging Inequalities (pp.80-92). $\mathrm{CABI}$, Oxford.

Alrawadieh, Z., Cetin, G., Dincer, M. Z., \& Istanbullu Dincer, F. (2020). The impact of emotional dissonance on quality of work life and life satisfaction of tour guides. The Service Industries Journal, 40(1-2), 50-64.

Alrawadieh, Z., Demirdelen Alrawadieh, D., Olya, H., Erkol Bayram, G., Kahraman, O.C. (2021). Sexual harassment, psychological well-being, and job satisfaction of female tour guides: The effects of social and organizational support, Journal of Sustainable Tourism https://doi.org /10.1080/09669582.2021.1879819

Babakus, E., Yavas, U., \& Ashill, N. J. (2009). The role of customer orientation as a moderator of the job demandburnout-performance relationship: A surface-level trait perspective. Journal of Retailing, 85(4), 480-492.

Brotheridge, C. M., \& Grandey, A. A. (2002). Emotional labor and burnout: Comparing two perspectives of "people work". Journal of Vocational Behavior, 60(1), 17-39.

Brotheridge, C. M., \& Lee, R. T. (2003). Development and validation of the emotional labour scale. Journal of Occupational and Organizational Psychology, 76(3), 365-379.

Brown, K., \& Westaway, E. (2011). Agency, capacity, and resilience to environmental change: lessons from human development, well-being, and disasters. Annual Review of Environment and Resources, 36.

Cetin, G., \& Yarcan, S. (2017). The professional relationship between tour guides and tour operators. Scandinavian Journal of Hospitality and Tourism, 17(4), 345-357.

Chen, C. F., \& Kao, Y. L. (2012). Investigating the antecedents and consequences of burnout and isolation among flight attendants. Tourism Management, 33(4), 868874.

Chen, Z., Sun, H., Lam, W., Hu, Q., Huo, Y., \& Zhong, J. A. (2012). Chinese hotel employees in the smiling masks: Roles of job satisfaction, burnout, and supervisory support in relationships between emotional labor and performance. The International Journal of Human Resource Management, 23(4), 826-845.

Cheng, J. C., \& Yi, O. (2018). Hotel employee job crafting, burnout, and satisfaction: The moderating role of perceived organizational support. International Journal of Hospitality Management, 72, 78-85.

Chiang, C. F., \& Liu, B. Z. (2017). Examining job stress and burnout of hotel room attendants: internal marketing and organizational commitment as moderators. Journal of Human Resources in Hospitality \& Tourism, 16(4), 367-383.

Chu, K. H. L., \& Murrmann, S. K. (2006). Development and validation of the hospitality emotional labor scale. Tourism Management, 27(6), 1181-1191.

Chu, K. H., Baker, M. A., \& Murrmann, S. K. (2012). When we are onstage, we smile: The effects of emotional labor on employee work outcomes. International Journal of Hospitality Management, 31(3), 906-915.

Cropanzano, R., Weiss, H. M., \& Elias, S. M. (2003). The impact of display rules and emotional labor on psychological well-being at work. In Emotional and physiological processes and positive intervention strategies. Emerald Group Publishing Limited. 
DeConinck, J. B. (2010). The effect of organizational justice, perceived organizational support, and perceived supervisor support on marketing employees' level of trust. Journal of business research, 63(12), 1349-1355.

Deery, M. \& Jago, L. (2009). A Framework For Work-Life Balance Practices: Addressing The Needs of The Tourism Industry. Tourism and Hospitality Research, 9(2), 97-108.

Delle Fave, A., Massimini, F., \& Bassi, M. (2011). Hedonism and eudaimonism in positive psychology. In Psychological selection and optimal experience across cultures (pp. 3-18). Springer, Dordrecht.

Diener, E. D., Emmons, R. A., Larsen, R. J., \& Griffin, S. (1985). The satisfaction with life scale. Journal of Personality Assessment, 49(1), 71-75.

Dolnicar, S. (2020). Why quantitative papers based on primary data get desk-rejected by Annals of Tourism Research. Annals of Tourism Research, 83, 102981.

Eger, R. J., \& Maridal, J. H. (2015). A statistical meta-analysis of the wellbeing literature. International Journal of Wellbeing, 5(2).

Eisenberger, R., Huntington, R., Hutchison, S., \& Sowa, D. (1986). Perceived organizational support. Journal of Applied psychology, 71(3), 500-507.

Faul, F., Erdfelder, E., Buchner, A., \& Lang, A. G. (2009). Statistical power analyses using G* Power 3.1: Tests for correlation and regression analyses. Behavior research methods, 41(4), 1149-1160.

Gursoy, D., Boylu, Y., \& Avci, U. (2011). Identifying the complex relationships among emotional labor and its correlates. International Journal of Hospitality Management, 30(4) 783-794.

Hair Jr, J. F., Hult, G. T. M., Ringle, C., \& Sarstedt, M. (2017). A primer on partial least squares structural equation modeling (PLS-SEM). Sage publications.

Han, S. J., Bonn, M. A., \& Cho, M. (2016). The relationship between customer incivility, restaurant frontline service employee burnout and turnover intention. International Journal of Hospitality Management, 52, 97-106.

Henseler, J., Ringle, C. M., \& Sarstedt, M. (2015). A new criterion for assessing discriminant validity in variancebased structural equation modeling. Journal of the Academy of Marketing Science, 43(1), 115-135.

Hochschild, A. R. (1983). The managed heart: Commercialization of human feeling. Berkeley: University of California Press.

Hofmann, V. \& Stokburger-Sauer, N. E. (2017). The Impact Of Emotional Labor On Employees' Work-Life Balance Perception And Commitment: A Study in The Hospitality Industry. International Journal Of Hospitality Management, 65, 47-58.

Hur, W. M., Moon, T. W., \& Jun, J. K. (2013). The role of perceived organizational support on emotional labor in the airline industry. International Journal of Contemporary Hospitality Management, 25(1), 105123.

Hwa, M. A. C. (2012). Emotional labor and emotional exhaustion: does co-worker support matter?. Journal of Management Research, 12(3), 115-127.

Kahneman, D., Diener, E., \& Schwarz, N. (Eds.). (1999). Wellbeing: Foundations of hedonic psychology. Russell Sage
Foundation.

Kang, B., Twigg, N. W., \& Hertzman, J. (2010). An examination of social support and social identity factors and their relationship to certified chefs' burnout. International Journal of Hospitality Management, 29(1), 168-176.

Karatepe, O. M. \& Aleshinloye, K. D. (2009). Emotional Dissonance and Emotional Exhaustion Among Hotel Employees in Nigeria. International Journal of Hospitality Management, 28(3), 349-358.

Karatepe, O. M. (2011). Do job resources moderate the effect of emotional dissonance on burnout?. International Journal of Contemporary Hospitality Management. 23(1), 44-65.

Kaya, U. \& Özhan, Ç. K. (2012). Duygusal emek ve tükenmişlik ilişkisi: turist rehberleri üzerine bir araştırma. Çalışma ilişkileri Dergisi, 3(2), 109-130.

Kim, Y., \& Back, K. J. (2012). Antecedents and consequences of flight attendants' job satisfaction. The Service Industries Journal, 32(16), 2565-2584.

Knobloch, U., Robertson, K., \& Aitken, R. (2017). Experience, emotion, and eudaimonia: A consideration of tourist experiences and well-being. Journal of Travel Research, 56(5), 651-662.

Koo, B., Yu, J., Chua, B. L., Lee, S., \& Han, H. (2020). Relationships among emotional and material rewards, job satisfaction, burnout, affective commitment, job performance, and turnover intention in the hotel industry. Journal of Quality Assurance in Hospitality \& Tourism, 21(4), 371-401.

Lee, J., Ok, C. M., Lee, S. H., \& Lee, C. K. (2018). Relationship between emotional labor and customer orientation among airline service employees: Mediating role of depersonalization. Journal of Travel Research, 57(3), 324-341.

Lu, A. C. C., \& Gursoy, D. (2016). Impact of job burnout on satisfaction and turnover intention: do generational differences matter?. Journal of Hospitality \& Tourism Research, 40(2), 210-235.

Lv, Q., Xu, S., \& Ji, H. (2012). Emotional labor strategies, emotional exhaustion, and turnover intention: An empirical study of Chinese hotel employees. Journal of Human Resources in Hospitality \& Tourism, 11(2), 87105.

Mackenzie, S. H. \& Kerr, J. H. (2013). Stress And Emotions At Work: An Adventure Tourism Guide's Experiences. Tourism Management, 36, 3-14.

Martínez-Iñigo, D., Totterdell, P., Alcover, C. M., \& Holman, D. (2007). Emotional labour and emotional exhaustion: Interpersonal and intrapersonal mechanisms. Work \& Stress, 21(1), 30-47.

Mastracci, S. H., \& Adams, I. T. (2020). It's not depersonalization, It's emotional labor: Examining surface acting and use-of-force with evidence from the US. International Journal of Law, Crime and Justice, 61 1-12.

Mcginley, S. \& Wei, W. (2018). Emotional Labor's Impact On Hoteliers Outside The Workplace. International Journal of Contemporary Hospitality Management, 30(9), 2965-2983.

Nawijn, J., \& Filep, S. (2016). Two directions for future tourist well-being research. Annals of Tourism Research, 61(C), 
221-223.

Pizam, A. (2004). Are Hospitality Employees Equipped To Hide Their Feelings?. International Journal of Hospitality Management, 23, 315-316.

Rasoolimanesh, S. M., Roldán, J. L., Jaafar, M., \& Ramayah, T. (2017). Factors influencing residents' perceptions toward tourism development: Differences across rural and urban world heritage sites. Journal of Travel Research, 56(6), 760-775.

Rhoades, L., \& Eisenberger, R. (2002). Perceived organizational support: a review of the literature. Journal of applied psychology, 87(4), 698-714.

Saayman, M., Li, G., Uysal, M., \& Song, H. (2018). Tourist satisfaction and subjective well-being: An index approach. International Journal of Tourism Research, 20(3), 388-399.

Şahin, S., \& Şad, B. (2018). Otel çalışanlarının tükenmişlik düzeyinin yaşam doyumuna etkisi. Seyahat ve Otel İsletmeciliği Dergisi, 15(2), 461-480.

Shanock, L. R., \& Eisenberger, R. (2006). When supervisors feel supported: Relationships with subordinates' perceived supervisor support, perceived organizational support, and performance. Journal of Applied psychology, 91(3), 689.

Singh, J., Verbeke, W., \& Rhoads, G. K. (1996). Do organizational practices matter in role stress processes? A study of direct and moderating effects for marketingoriented boundary spanners. Journal of Marketing, 60(3), 69-86.

Sirgy, M. J., Efraty, D., Siegel, P., \& Lee, D. J. (2001). A new measure of quality of work life ( $Q W L$ ) based on need satisfaction and spillover theories. Social Indicators Research, 55(3), 241-302.

Van Dijk, P. A., \& Brown, A. K. (2006). Emotional labour and negative job outcomes: An evaluation of the mediating role of emotional dissonance. Journal of management and Organization, 12(2), 101-115.

Voorhees, C. M., Brady, M. K., Calantone, R., \& Ramirez, E. (2016). Discriminant validity testing in marketing: an analysis, causes for concern, and proposed remedies. Journal of the Academy of Marketing Science, 44(1), 119-134.

Walters, G., \& Raybould, M. (2007). Burnout and perceived organizational support among front-line hospitality employees. Journal of Hospitality and Tourism Management, 14(2), 144-156.

Wang, C. J. (2020). Managing emotional labor for service quality: A cross-level analysis among hotel employees. International Journal of Hospitality Management, 88, 1-12.

Wen, J., Huang, S. S., \& Hou, P. (2019). Emotional intelligence, emotional labor, perceived organizational support, and job satisfaction: A moderated mediation model. International Journal of Hospitality Management, 81, 120-130.

Wong, J. Y. \& Wang, C. H. (2009). Emotional Labor Of The Tour Leaders: An Exploratory Study. Tourism Management, 30(2), 249-259.

Woo, E., Kim, H., \& Uysal, M. (2015). Life satisfaction and support for tourism development. Annals of tourism research, 50, 84-97.
Xu, S. T., Cao, Z. C., \& Huo, Y. (2020). Antecedents and outcomes of emotional labour in hospitality and tourism: A meta-analysis. Tourism Management, 79, 104099.

Yetgin, D., \& Benligiray, S. (2019). The effect of economic anxiety and occupational burnout levels of tour guides on their occupational commitment. Asia Pacific Journal of Tourism Research, 24(4), 333-347.

Zhao, X., Lynch Jr, J. G., \& Chen, Q. (2010). Reconsidering Baron and Kenny: Myths and truths about mediation analysis. Journal of Consumer Research, 37(2), 197-206.

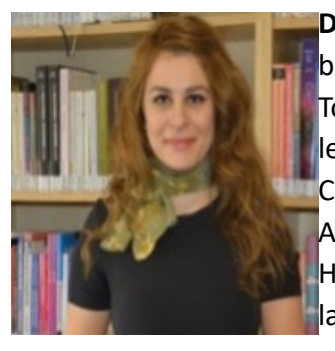

Derya Demirdelen Alrawadieh obtained both her Master's and Ph.D. degrees in Tourism Management. Currently, she ectures in the Hotel, Restaurant, and Catering Services Department at Istanbul Ayvansaray University, Istanbul, Turkey. Her research interests include emotional abour and well-being in tourism services, organizational behaviour, and gender studies. She has published in high tier journals including Journal of Sustainable Tourism and International Journal of Culture, Tourism and Hospitality Research.

\section{ORCID: 0000-0002-7554-2256}

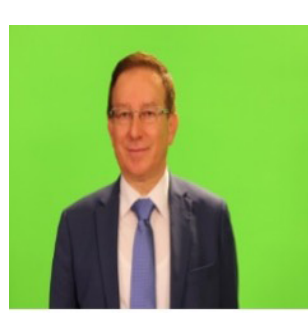

Mithat Zeki Dincer is a Full Professor at the Department of Economic Policy, Faculty of Economics, Istanbul University. He holds a Ph.D. degree on tourism from the Faculty of Economics at Istanbul University. His current research interests include tourism economics, tourism development and economic policy. $\mathrm{He}$ is also member of editorial board for several

tourism studies-related journals..

ORCID: 0000-0002-4928-8303 